\title{
分布型モデルへの適用を目的とした 森林小流域における降雨流出モデルの提案 PROPOSAL OF RAINFALL-RUNOFF MODEL FOR FORESTED SUB-BASINS APPLYING TO DISTRIBUTED MODEL
}

\author{
山下 三男 1 ・市川 新 ${ }^{2}$ \\ Mitsuo YAMASHITA and Arata ICHIKAWA

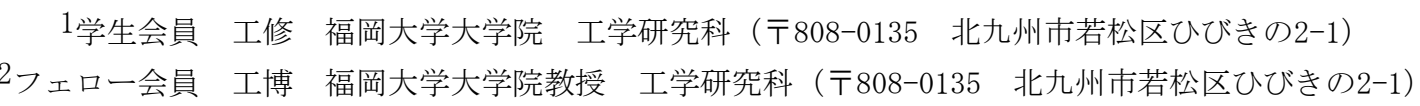

The application of a distributed model for river basins is keen issue. However methodologies for its application have not fully discussed. As for river water simulation models, there are fully developed commercial models with the progress of mathematical techniques for hydraulic calculation. The next topic is a description of rainfall runoff phenomena in sub-basins for river water simulation models. Especially in Japan, the upstream areas of rivers are almost covered with forests. A rainfall-runoff model for forested sub-basins is necessary for continuous simulation including several rainfall events and dry weather periods. In this paper, the authors proposed the pseudo-physical rainfall-runoff model for forested area on the assumption that surface and inter flow are related to void ratio and wetness of soil. They applied this model for a mountainous forested basin as one of distributed models. The simulation results fairly agreed with observed data.

Key Words : distributed model ,retention capacity, inter flow, SCS-CN method, continuous simulation, soil pores, identification of parameters

\section{1. はじめに}

降雨によりどのように流量が変化するかという課題 は, 古くて新しい問題である. 流出現象が複雑である こと，対象とする流域の条件が多様であることから， 今までは集中型モデルが主流であったが，河川の任意 地点における任意時刻の水位, 流速及び水質といった 詳細な情報が要求されるようになると, 集中型モデル ではそれに応えることが出来ない. そこで分布型のシ

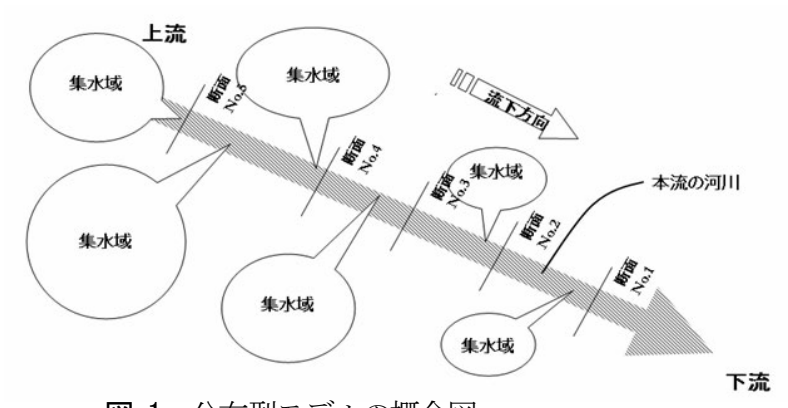

図-1＼cjkstart分布型モデルの概念図
ミュレーションモデルが注目され, 多くの研究者, 実 務家により研究が始められている. 分布型モデルは

「地形や流出特性によって流域を分割し，そこからの 流出を河川への入力とし, 河川の中の流れは物理的な モデルで追跡する.」という概念である.（図-1）

分布型モデルでは流域の分割数の定義はない. 例え ば左右両岸をそれぞれ別の小流域としても分布型とな るし，いくつかの大きな支川ごとに分割することも分 布型モデルということが出来る. しかし, 近年都市域 の雨水流出解析では，下水道のマンホールごとに小流 域を分割する分布型モデルが，開発され実用化されて いる．市販されているモデルを用いれば，流域を 10 万 近くまで分割することが可能であり，マンホールの設

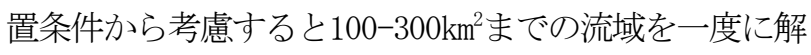
析できるようになっており，実際にもその程度の規模 での解析が行われている1). しかし，河川を対象とする 場合には，ここまで規模を小さくした解析はまだ行わ れていない.

分布型モデルのもう1つの例に流域をグリッドにより 


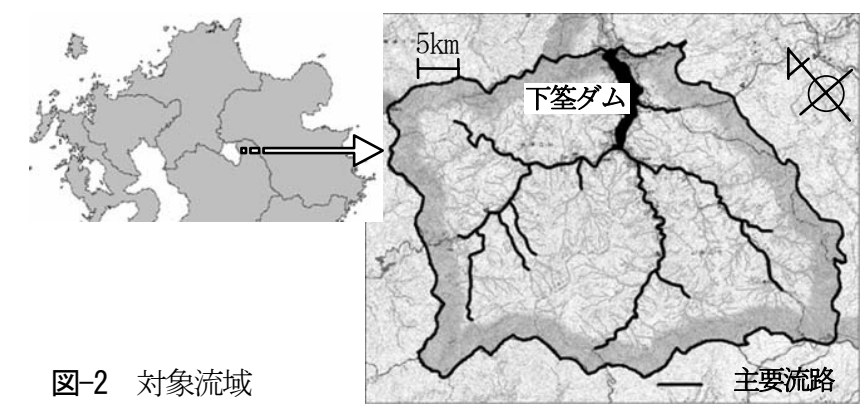

分割するモデルがある. 1984年に市川ら²によって，流 域を $10 \mathrm{~m}$ メシュで分割する「メッシュ法」が提言さ れたが，「メッシュ間の移動速度」を降雨条件，地形 により変化させることが出来ず，その解決が今後の課 題であると報告している3).

筆者らは小流域のサイズをできるだけ小さく設定す ることがこれからの課題であると考え, それに伴うさ まざまな課題の研究を行ってきた. 本報告では, 流域 をできるだけ小さくし，そこでの流出機構を『集中型 モデル』で表現する方法を提言する．そのためには小 流域ごとの降雨・流量の観測データが必要であるが, そのような試験流域のデータが得られなかったので, 正確な流量観測が行われているダム上流部を対象とし て，考察を行った。 具体的には，筑後川の下鉒ダム上 流域の大分県日田郡上津江村, 中津江村 (現在日田市に 編入されている)である. 流域面積は $182 \mathrm{~km}^{2}$ であり, 位 置を図-2に示寸. ダム地点の流量は, ダムの水位変化 に伴う貯留量変化と, 下流への放流量加逆算して求 められている. 降雨量は流域内外の12 所の降雨観測 点における時間降雨量を用いている.

\section{2. 分布型モデルに必要な降雨流出モデル の位置づけ}

小流域からの流出量は『集中型モデル』で記述しな ければならない. 理論的にはRichards式を解く浸透解 析法が現時点で物理現象を正確に表現するものとして 評価されているが，それに必要な土壌毎の多くのパラ メータを同定することはほとんど不可能であり, ライ シメータのような小さな対象に対するものが多く, 直 接全流域に適用寸るまでには至っていない，そこで夕 ンクモデルや貯留関数法に代表されるような「概念モ デル」が実務的に広く利用されている。これは降雨・ 流出の変換過程がブラックボックスであり, 必要なパ ラメータは過去の観測データから同定されるため, 流 域としての一般解を求めることは不可能に近い. 本来 これらの降雨流出モデルのパラメータは植生, 土袞, 土地利用などの地表の状態から同定できるものである がその推定法は存在しない.

そこで筆者らは，出来るだけ物理現象に忠実で，か

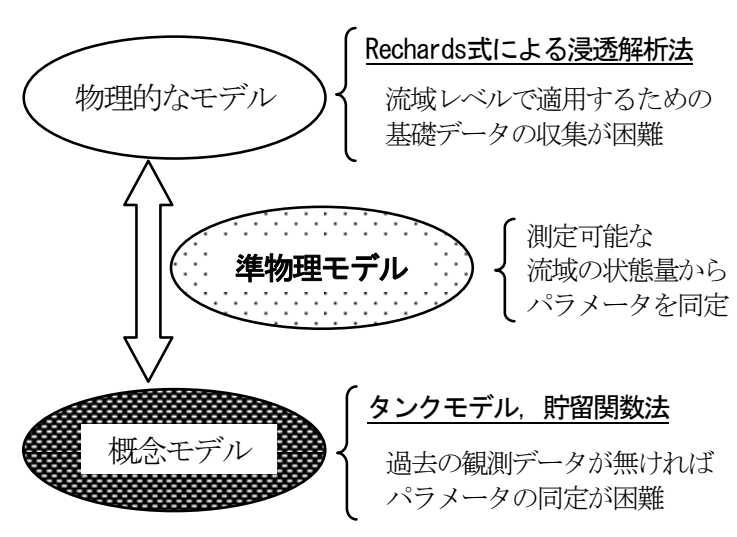

図-3＼cjkstart準物理モデルの位置づけ

つ実務的にも利用可能なモデル，すなわち『物理モデ ル』と『概念モデル』の中間に位置する実用性の高い 「準物理モデル」（図-3）が必要と考え，河川の源流域 の大部分を占める森林流域を対象としたモデルを構築 したのでここに報告する.

なお，小流域に分割することにより，必要となる流 域の小流域一の分割 (4)，降雨データの内挿法 ${ }^{5}$ ，河道の

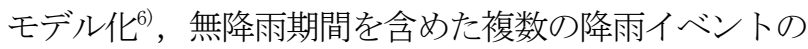
連続シミュレーションわについてはそれぞれすでに報告 したので，ここでは省略する.

\section{3. 提言するモデルの基本概念}

森林流域においては, 雨水の浸透とその再流出が下 流のハイドログラフに大きな影響を与えていると考え られる，そこで，図-4に示すように，降雨が早い段階 で流出する「表面流」，浸透した雨水の再流出である 「中間流」及び地下水の流出のようきわめて緩やかに 増減する「基底流出」によって流出水が構成されると した，具体的には，地上に到達した雨(P) は土壤表面に おいて, 表面流出 $\left(\mathrm{P}_{\mathrm{e}}\right)$ と土壌へ浸透する「貯留への入 力」 $\left(\mathrm{P}-\mathrm{P}_{\mathrm{e}}\right)$ 一分離され, 土壌において貯留される水か ら蒸発散, 地下水への補給及び中間流としての流出 $(\mathrm{M})$

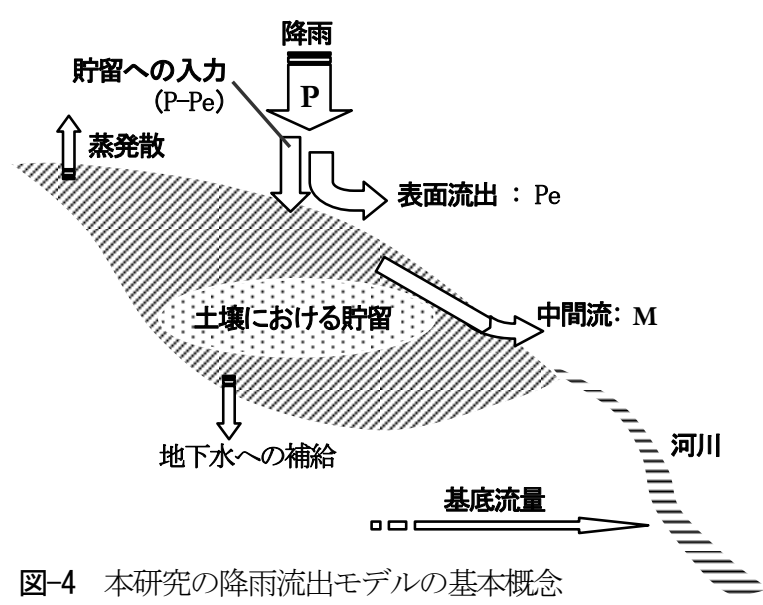


が起きるとし, 流域の土壌における固有の「貯留容 量」と「その貯留水量の変化」が流出現象に支配的な 影響を与えると仮定したものである.

国内においては，表面流出量を推定するにあたって， 累積降雨量が飽和雨量に達するまで, 流出率が一定と 仮定して流出が起こるものとし, 飽和雨量に達した後 は降雨のほぼ全量が流出するという方法が広く用いら れている8 . しかし, 飽和雨量に達した後に流出率が急 に 1 になるというのは不連続な考え方であり, 土壤に おける浸透能力が高い森林流域一の適用には問題があ る. また, 先行降雨の影響により土㙥の湿潤状態は大 きく変化するので, 飽和雨量の值は雨ごとに降雨直前 の状況によって異なると考えられる.

このような考えに近いものとして, 米国土壌保全局 (Soil Conservation Service; SCS) が開発したU.S. Soil Conservation Service Curve Number method (SCS-CN法) $)^{9)}$ があ.

SCS-CN法の優れた点は「降雨の継続に伴い，土壤へ 浸透する雨の量は減少していき, やがてまったく浸透 しなくなり，降雨の全量が流出するようになる」とい う基本概念にある. SCS-CN法の詳細については既報10)で 述べたがその基本概念を以下に述べる.

SCS-CN法の基本式を(1a)，(1b)に示寸.

$$
\begin{aligned}
& \mathbf{P}=\mathbf{I}_{\mathbf{a}}+\mathbf{F}+\mathbf{P}_{\mathbf{e}} \\
& \frac{\mathbf{P}_{\mathbf{e}}}{\mathbf{P}-\mathbf{I}_{\mathbf{a}}}=\frac{\mathbf{F}}{\mathbf{S}}
\end{aligned}
$$

ここに, P; 累積降雨量 $(\mathrm{mm}), \mathrm{I}_{\mathrm{a}}$; 初期損失 $(\mathrm{mm}), \mathrm{P}_{\mathrm{e}}$; 表面流出の累積量 $(\mathrm{mm}), \mathrm{F}$; 累積浸透量 $(\mathrm{mm}), \mathrm{S}$; 許容 最大貯留量 $(\mathrm{mm})$ である.

ここでいう許容最大貯留量 $(\mathrm{S})$ は，「降雨の継続に伴 う累積浸透量(実際には初期損失も含まれるのでそれと 累積浸透量の合計量)の最大值」を意味する.

$\mathrm{SCS}$ は初期損失 $\left(\mathrm{I}_{\mathrm{a}}\right)$ をSの $20 \%$ の值であると仮定するこ とで(1a)，(1b)式から (2)式を導出している.

$$
\left.\begin{array}{ll}
\mathbf{P}_{\mathbf{e}}=0 & (0 \leq \mathrm{P} \leq 0.2 \mathrm{~S}) \\
\mathbf{P}_{\mathbf{e}}=\frac{(\mathbf{P}-0.2 \mathbf{S})^{2}}{\mathbf{P}+0.8 \mathrm{~S}} & (\mathrm{P}>0.2 \mathrm{~S})
\end{array}\right\}
$$

(2) 式の意味するところは，唯一のSというパラメー タさえ同定すれば, 累積降雨量(P) から表面流出の累積 量 $\left(\mathrm{P}_{\mathrm{e}}\right)$ が推定できるということである.

そこで，既報》においては，SCS-CN法を暫定的に表面 流の推定モデルとして採用し, 中間流に関してはSCS$\mathrm{CN}$ 法を補足する形での新たな中間流モデルを考案して 適用した。
しかしながら，この方法を実際に分布型モデルの小 流域へ適用したところ, 以下の $4 つ の$ 課題があることが 判明した.

\section{（1）単一の降雨イベントのためのモデルであること}

SCS-CN法は，想定される一定の降雨強度の計画降雨 に対し，ピーク流量と総流出量を推定するために開発 されたものである9)。この方法は都市流域及び農地流域 において比較的精度良く流出量を推定できるため, 実 際の観測ハイエトグラフから (2) 式によって単位時間毎 に計算した結果を時間で微分して，擬似的に有効降雨 のハイエトグラフを作成し，それに米国農務省資源保 護局の無次元単位図 (Dimensionless Hydrograph) ${ }^{11}$ を適 用してハイドログラフを得るという方法が便宜的に用 いられてきた。

しかし，この方法は本来，単一の降雨強度が一定の 降雨イベントを対象としたもので, 複数の降雨イベン 卜や降雨強度が変化する降雨イベントに適用する場合, 各降雨イベント開始時に，あるいは時間毎にSの值を更 新しなければならない，前者の場合，独立した降雨イ ベントの定義が問題になる，具体的にいえば，雨がど のくらいの時間やめば，その前後を「別々」の降雨イ ベントと判断してSの值を更新させるかである。これに より, 流出量の推定結果は大きく異なるものとなる.

既報》のシミュレーションでは，「降雨が1時間の間 停止したら，その前後は別々の降雨イベントであ る.」と仮定していたが，これによりモデルに曖昧な 点を残すこととなった.

\section{（2）初期損失と浸透量がまとめられていること}

Sの值は，基本的に土壤における貯留能力の指標であ ると考えられるが, 初期損失をも含む值であるので, 概念的に曖昧なものとなっている。

\section{（3）貯留された水の排水が考慮されていないこと}

SCS-CN法では, 降雨の継続中は浸透した水が土壤の 中に溜まる一方であるとして, 表面流を推定する考え 方である。しかし，とくに日本の森林のように急峻な 勾配を有している地形においては，降雨が継続してい ても，一旦土㙲孔隙に入った水は蒸発散，中間流や降 下浸透といった様々な形態で流出すると考えられ, そ の結果, 降雨が継続していても, 降雨強度が小さくな れば貯留量が減少することもあると思われる。よって, 降雨の開始時にSの值を更新寸るのではなく, 連続的に, 物理的な現象と関連づけて考える必要がある.

\section{(4) 国内ではパラメータが一般化されていないこと}

Sの值は小流域固有のものであるが，米国においては 長年その実測が行われており, 先行降雨条件, 様々な 地質, 植生, 土地利用に応じた值が決められている. 


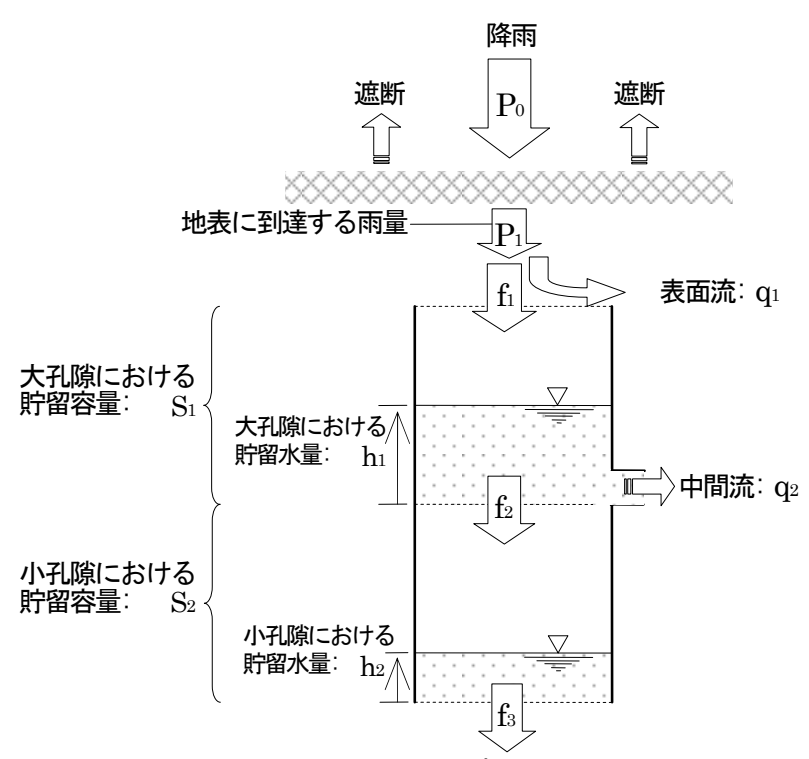

図-5山下モデルの構造

損失

しかし，日本においてはそのような観測例がないため， SCS-CN法を適用するには，実際の降雨量と流出量からS の值を推定しなければならない.

そこで，これらの課題を克服できるモデルを構築す ることとした.

\section{4. 基本概念の具現化}

\section{（1）現象を連続的に記述する基本構造}

一雨毎に飽和貯留量を変化させるのではなく, 物理 的な「貯留容量」と連続的な貯留水量の変化に応じた 流出の変化を記述できるようにすることを目的として， 土壤における2段階の貯留構造を仮定する「山下モデ ル」を考案した．図-5はその概念図であり，モデルに おける計算過程を模式化したものである. 実際の土壌 中では大孔隙と小孔隙が混在していると思われるが, それを分けて表示している. これは土質力学等の教科 書において, 土袞と土粒子, 水で飽和されている空隙 及び空気の存在する空隙とを分けて模式化されている のと同じ考え方である.

ここで, 重要な因子である大孔隙における貯留容量 $\left(\mathrm{S}_{1}\right)$ 及び小孔隙における貯留容量 $\left(\mathrm{S}_{2}\right)$ については, 森林 土壤学で実測されている值を利用することとした。こ れは土壌孔隙における保水容量を, 真下の方法 ${ }^{12)}$ に基づ いて調查し, $p F$ 值に応じて大孔隙保水容量 $(\mathrm{pF} 0 \sim 0.6)$, 中小孔隙保水容量 $(\mathrm{pF} 0.6 \sim 2.7)$ 及び細孔隙保水容量 (pF2.7以上) に分類したものである.

\section{（2）表面流の推定}

まず，SCS-CN法では曖昧であった初期損失と浸透量 をより峳密に区分するため, 森林の樹冠における遮断
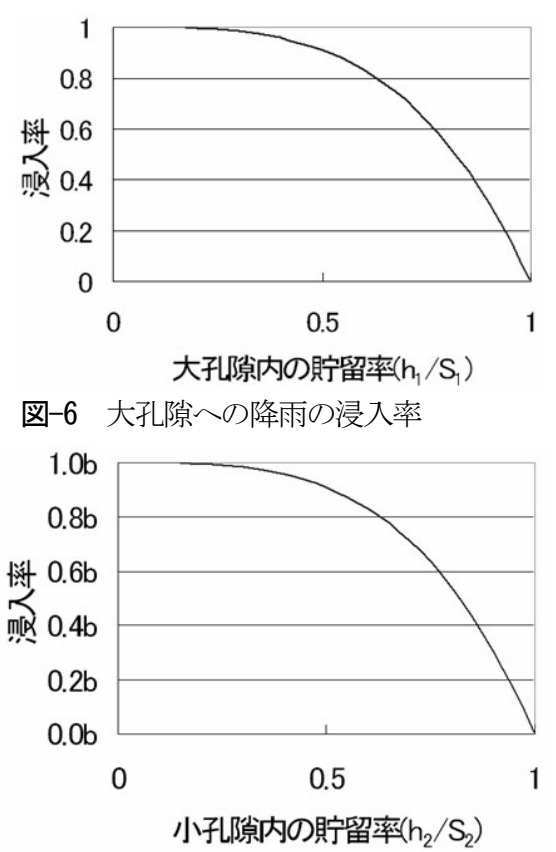

図-7 大孔隙から小孔隙への水の浸入率

降雨量を考慮し，地上に到達する雨量 $\left(\mathrm{P}_{1}\right)$ を求めること とした．樹冠遮断雨量については，様々な論文がある が，「樹冠遮断が降雨強度に比例（依存）する」とす るMurakami ${ }^{13)}$ の仮説に基づき, 観測降雨量 $\left(\mathrm{P}_{0}\right)$ から一律 20\%を遮断量として控除した.

雨水が浸透して貯留される場所としての土壌孔隙に 関しては，水が浸透しやすい「大孔隙」の貯留容量 $\left(\mathrm{S}_{1}\right)$ と緩やかに水が浸透してゆく「小孔隙」の貯留容量 $\left(\mathrm{S}_{2}\right)$ に分けられると仮定し，地上に到達した雨(P) はまず大 孔隙に浸透し $\left(\mathrm{f}_{1}\right)$, 浸透しきれない雨 $\left(\mathrm{P}-\mathrm{f}_{1}\right)$ が表面流出 $\left(\mathrm{q}_{1}\right)$ するとした.

その際，大孔隙に貯留されている水量 $\left(h_{1}\right)$ が少ないと きは，降雨のほぼ全量が大孔隙に浸入するとし， $\mathrm{h}_{1}$ の值 が増加するとともに浸入しにくくなり，大孔隙がす心゙ て水で満たされると全く浸入せずに降雨の全量が表面 流として流出するとした(図-6).

以上の仮定を数学的に次式で表現することとした.

$$
\begin{aligned}
& \mathbf{P}_{1}=\mathbf{i}_{\mathbf{a}} \cdot \mathbf{P}_{0} \\
& \mathbf{f}_{1}=\mathbf{P}_{1} \cdot\left\{1-\left(\frac{\mathbf{h}_{1}}{\mathbf{S}_{1}}\right)^{\mathbf{a}_{1}}\right\} \\
& \mathbf{q}_{1}=\mathbf{P}_{1}-\mathbf{f}_{1}
\end{aligned}
$$

ここに, $\mathrm{P}_{0}$; 林外雨量 $(\mathrm{mm} / 5$ 分 $), \mathrm{P}_{1}$; 地表に到達する降 雨量 $(\mathrm{mm} / 5$ 分 $), \mathrm{i}_{\mathrm{a}}$; 樹冠遮断率, $\mathrm{h}_{1}$; 大孔隙における貯 留水量 $(\mathrm{mm}), \mathrm{S}_{1}$; 大孔隙の貯留容量 $(\mathrm{mm}), \mathrm{a}_{1}$; 大孔隙浸 入係数, $\mathrm{f}_{1}$; 大孔隙浸透量 $(\mathrm{mm} / 5$ 分 $), \mathrm{q}_{1}$; 表面流の有効 流出量 $(\mathrm{mm} / 5$ 分) である. パラメータの同定に関しては, 
中間流の項で述べる.

これらの過程によって計算された表面流の有効流出 量は, 米国農務省資源保護局の無次元単位図 (peak rate factor $=70)^{11)}$ によってハイドログラフに変換した.

\section{(3) 中間流の推定}

貯留された雨水の排水を考慮するため, 大孔隙にお いて貯留された水は，小孔隙に移動する水 $\left(\mathrm{f}_{2}\right)$ と中間流 $\left(\mathrm{q}_{2}\right)$ として排水されると仮定した. 中間流 $\left(\mathrm{q}_{2}\right)$ は大孔隙 における貯留量 $\left(\mathrm{h}_{1}\right)$ に応じて流出量が変化するとした. 大孔隙から小孔隙に移動する水 $\left(f_{2}\right)$ についても, $h_{1}$ に応 じてその量が変化するとしたが， $\mathrm{f}_{1}$ と同様にすでに小孔 隙内に貯留されている水量 $\left(\mathrm{h}_{2}\right)$ が貯留容量 $\left(\mathrm{S}_{2}\right)$ に近づく につれ，その量が少なくなり，やがて零になるとした (図-7).

小孔隙内に貯留された水は，その水量 $\left(\mathrm{h}_{2}\right)$ に応じ降下 浸透や蒸発散による損失 $\left(\mathrm{f}_{3}\right)$ として失われるとした.

以下に中間流を推定するための基本式を示す.

$$
\begin{aligned}
& \mathbf{f}_{2}=\mathbf{h}_{1} \cdot \mathbf{b} \cdot\left\{1-\left(\frac{\mathbf{h}_{2}}{\mathbf{S}_{2}}\right)^{\mathbf{a}_{2}}\right\} \\
& \mathbf{q}_{2}=\mathbf{c} \cdot \mathbf{h}_{1} \\
& \mathbf{f}_{3}=\mathbf{d} \cdot \mathbf{h}_{2}
\end{aligned}
$$

ここに， $\mathrm{h}_{2}$; 小孔隙における貯留水量 $(\mathrm{mm}), \mathrm{S}_{2}$; 小孔隙 の貯留容量 $(\mathrm{mm}), \mathrm{a}_{2}$; 小孔隙浸入係数, $\mathrm{b}$; 土壤固有の 大孔隙力ら小孔隙への水の浸入率 $\left((5 \text { 分 })^{-1}\right), \mathrm{f}_{2}$; 小孔隙 浸透量 $(\mathrm{mm} / 5$ 分 $), \mathrm{c}$; 中間流出係数 $\left((5 \text { 分 })^{-1}\right), \mathrm{q}_{2}$; 中間 流の有効流出量 $(\mathrm{mm} /(5$ 分 $)), \mathrm{d}$; 損失係数 $\left((5 \text { 分 })^{-1}\right), \mathrm{f}_{3}$; 損失量 $(\mathrm{mm} / 5$ 分 $)$ である.

このような仮定とすることにより，降雨期間中の土 壤中の水分量の変化を連続的に記述することが可能と なった.

山下モデルには，大孔隙浸入係数 $\left(\mathrm{a}_{1}\right)$, 小孔隙浸入係 数 $\left(\mathrm{a}_{2}\right)$, 土㙥固有の大孔隙から小孔隙への水の浸入率 (b), 中間流出係数 $(c)$, 損失係数 $(d)$, 大孔隙の貯留容 量 $\left(\mathrm{S}_{1}\right)$ 及び小孔隙の貯留容量 $\left(\mathrm{S}_{2}\right)$ の 7 のパラメータが ある.

$\mathrm{S}_{1}$ 及び $\mathrm{S}_{2}$ については，諌本ら ${ }^{14)}$ が，大分県下の 45 カ所 の森林で行った結果を参照した. 当初は $\mathrm{S}_{1}$ 及び $\mathrm{S}_{2}$ の值と して, 諌本らの調査結果における対象流域中の観測地 点における大孔隙保水容量と中小孔隙保水容量の值を それぞれ採用したが，過大な貯留容量となることがわ かったので，その $50 \%$ の值を採用し， $\mathrm{S}_{1}=89 \mathrm{~mm}, \mathrm{~S}_{2}=127 \mathrm{~mm}$ とした.

その他のパラメータにつては, 試行錯誤の結果, 5分 間隔の計算において, $\mathrm{a}_{1}=4, \mathrm{a}_{2}=4, \mathrm{~b}=0.001, \mathrm{c}=0.0014$ の值を採用した。損失係数については，降雨が停止し
てから概ね10日間降雨がなければ，貯留された水はす べて失われると仮定し， $\mathrm{d}=0.001$ とした.

流域における測定值が一箇所のものしか入手できな かったので，第 1 近似としてこれらのパラメータの值 を分布型モデルにおける全小流域に適用した。

これらの過程によって計算された中間流の有効流出 量は，既に報告した中間流単位図 ${ }^{4)}$ 適用しハイドログ ラフに変換した.

\section{（4）基底流量の推定}

基底流量については，対象流域における過去三年間 の晴天時流量を解析し ${ }^{15)}$, 先行20日間の降雨履歴との関 係から，(9a)，(9b)の近似式を仮定し，シミュレーショ ンに適用した。

$$
\begin{aligned}
& \mathbf{B F}=\left(0.040 \cdot \sum_{\mathbf{n}=1}^{\mathbf{m}} \frac{\mathbf{n}}{\mathbf{m}} \mathbf{P}_{\mathbf{n}}+1.063\right) \cdot 10^{-2} \cdot \mathbf{A} \\
& \mathrm{m}=\frac{20_{(\text {日) }} \times 24_{\text {(時間) }} \times 60_{(\text {分 })}}{5 \text { (分) }}
\end{aligned}
$$

ここに，m；20日間をハイエトグラフの時間間隔(本研 究では5分) で割った数， $\mathrm{P}_{\mathrm{n}} ; 20$ 日前から数えてn番目の 地表に到達する降雨量 $\left(\mathrm{mm} / 5\right.$ 分), $\mathrm{A}$; 流域面積 $\left(\mathrm{km}^{2}\right)$, $\mathrm{BF}$ ；基底流量 $\left(\mathrm{m}^{3} / \mathrm{s}\right)$ である.

このようなモデル構造とすることにより，真下の方 法による土壌孔隙量 ${ }^{12)}$ のような物理的な測定值とモデル の主要なパラメータである $\mathrm{S}_{1}$ 及び $\mathrm{S}_{2}$ を関連付けることが 可能になると考えられる.

なお，このモデルはタンクモデルに似た構造である が，根本的に異なる点は，大孔隙と小孔隙というそれ ぞれの「タンク」に「容量」があり，容量が満たされ るにつれ，タンクに水が浸入しにくくなるという点で ある。

\section{5. 分布型モデルによるシミュレーション}

本研究の対象流域においては，観測流量データが流 域の出口である下鉒ダムのものしか得られなかったた め，既に報告した対象流域の分布型モデル77において， 各小流域に山下モデルを適用して流出ハイドログラフ を求め, 河道モデルに入力として与え, シミュレー ションより推定された下鉒ダムへの流入量を観測デー タと比較することにより，モデルの評価を行うことと した.

シミュレーションの対象期間は2004年6月24日正午よ り同年7月1日正午までの1週間とした。この期間を選ん だ理由は，過去10日間降雨がなく，大孔隙及び小孔隙 における初期貯留量を零と仮定してよいと考えたから である。 


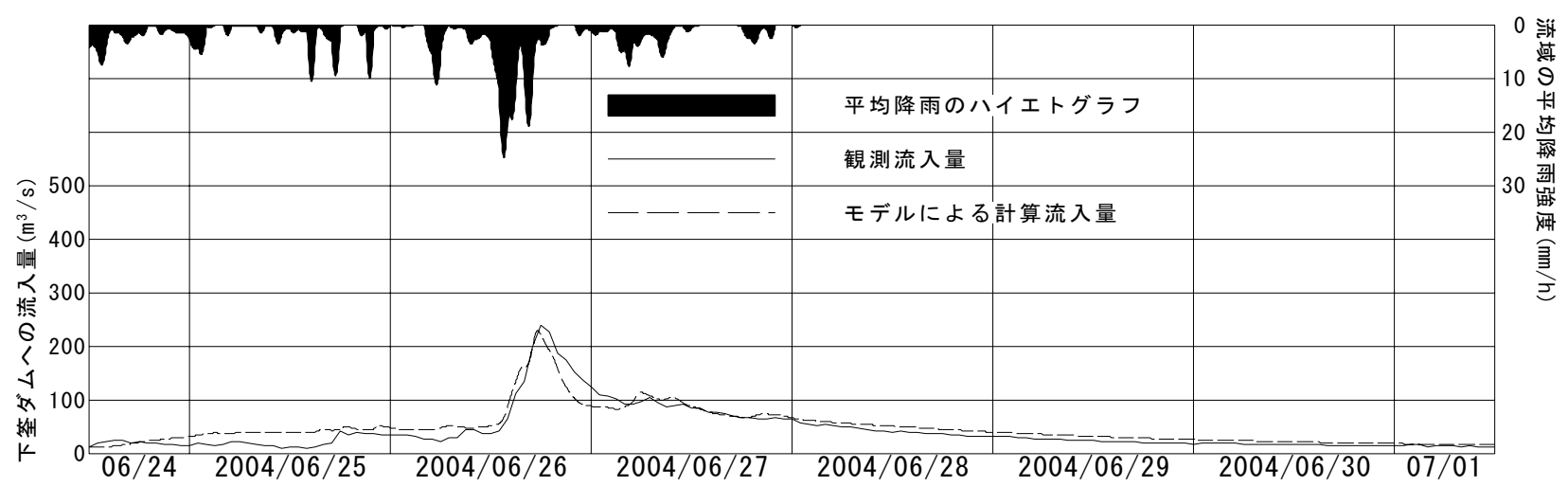

図-8山下モデルを用いた分布型モデルによるシミュレーション結果の一例(2004/06/24 12:00～07/01 12:00)

シミュレーションより推定された下鉒ダムへの流入 量を観測データと比較したものを図-8に示す.

シミュレーション結果は，概敞観測データの傾向を 再現しており, 山下モデルの基本的な概念に大きな誤 りはないと考えられる。

\section{6. おわりに}

観測可能な地表の状態からパラメータを同定するこ とが可能で，かつ降雨履歴に応じた土壌における貯留 能力の連続的な変化を考慮できるような降雨流出の 「準物理モデル」の開発を行ったが，現在のところ， 対象流域における1週間のシミュレーションでモデルを 検証したに過ぎない，一般化するには，様々な期間を 対象としたシミュレーションを行い，モデルの概念を 検証し，必要な修正を行う必要がある.

今後は総合地球環境学研究所の協力の下, 北海道大 学雨龍演習林の小流域観測データを用い, 主要な因子 である大孔隙及び小孔隙の貯留容量 $\left(\mathrm{S}_{1}, \mathrm{~S}_{2}\right)$ について, 実際に土壌孔隙の測定を行いながら，真下の方法 ${ }^{12)}$ 等に よる測定值と関連付けて一般化することが可能かどう か検証し，その他のパラメータについても，フィッ ティングによらない同定法を検討寸る予定である.

\section{参考文献}

1) 家壽田昌司, 松宮洋介, 黒住光浩, 狩谷薰：「改良型雨水 流出解析モデル」の開発と活用方法に関する提案, 下水道 協会誌論文集，40，No.494，pp. 107-126，2003

2) Ichikawa, A. and T. Sakakibara: A proposal of a new simulation model 'Grid Method' for urban storm runoff, Proc. of 3rd Inter. Conf. on Urban Storm Drainage, Vol.1, pp.245-253, 1984

3）市川新, Dejan Pavic : メッシュ法の都市河川流域への適用 一雨水流出抑制施設の評価（第 3 報），土木学会水理講演 会論文集，Vol.31，pp.41-46，1987

4) Yamashita, M., T. Tateishi and A. Ichikawa: A study on the application of the distributed rainfall-runoff model for the Japanese mountainous Area, Proc. of 3rd Inter. Symposium on Flood
Defence, Nijmegen, Netherlands, pp.477-486, 2005

5) Yamashita, M., T. Tateishi and A. Ichikawa: A study on the improvement of the applicability of the distributed river simulation model, Proc. of MTERM Inter. Conf., Asian Institute of Technology, Thailand, 2005

6）山下三男，市川新：分布型河川シミュレーションモデルの 適用性向上に関する研究，土木学会水工学論文集，Vol. 49, pp. 181-186, 2005

7）山下三男，市川新：分布型河川シミュレーションモデルに よる流域の水文情報の統合, 土木学会環境工学研究論文集, Vol. 42, pp. 101-110, 2005

8）（社）日本河川協会：建設省河川砂防技術基準(案) 同解説 調査編, 山海堂, pp. 90-91, 1997

9) Soil Conservation Service: Urban hydrology for small watersheds, Technical release, No.55, U.S. Department of Agriculture, 1975

10) Yamashita, M. and A. Ichikawa: A study on the unit hydrographs with US SCS method regarding to infiltrations, Inter. Symposium on Disaster Mitigation and Basin-Wide Water Management, Niigata, Japan, 2003

11) Natural Resources Conservation Service: Chapter 16 Hydrographs, Part 630 Hydrology, National Engineering Handbook, U.S. department of Agriculture, 2003

12）真下育久：土壌の理学性一吸収板による簡単な $\mathrm{pF}$ 価の測定 とこれによる土畩水および孔隙の区分-, 森林立地, Vol. 3, No. 1, pp. 32-34, 1961

13) Murakami, S.: A proposal for a forest canopy interception mechanism: Splash droplet evaporation, Journal of Hydrology, doi:10.1016/j.jhydrol.2005.07.002, Elsevier, 2005

14）諌本信義，高宮立身，山田康裕：大分県の貴重な天然林 及び代表的な人工林の総合調査, 大分県林業試験場研究報 告, Vol. 14, pp. 1-204, 2002

15）山下三男：US SCS法に基づく分布型雨水流出モデルの構 築に関する研究, 福岡大学大学院, 平成15年度 修士学位論 文，2004

(2005. 9. 30受付) 